\title{
POSSIBILITY OF CHOOSING DEVELOPMENT INVESTMENT PROGRAMS OF A PRODUCTION COMPANY BY APPLYING DISCOUNTED INVESTMENT APPRAISAL TECHNIQUE
}

\author{
UDC: $330.322: 005.311 .6$ \\ Original Scientific Paper
Jasmina VESIĆ VASOVIĆ ${ }^{1}$, Miroslav RADOJIČIĆ ${ }^{2}$, Zoran NEŠIĆ ${ }^{2}$, Djordje MIHAILOVIĆ ${ }^{3}$ \\ ${ }^{1}$ University of Kragujevac, Faculty of Technical Sciences Čacak, 32000 Čacak, Svetog Save 65, \\ Republic of Serbia \\ E-mail: jasmina.vesic@gmail.com \\ ${ }^{2}$ University of Kragujevac, Faculty of Technical Sciences Čacak, 32000 Čacak, Svetog Save 65, \\ Republic of Serbia \\ ${ }^{3}$ High Technological School of Applied Studies, 34300 Aranđelovac, Josifa Pančića 11, Republic of \\ Serbia
}

Paper received: 05.05.2014.; Paper accepted: 21.05.2014.

\begin{abstract}
The selection of development investment programs is one of the most important decisions in industrial production. The paper sets out the possibilities of applying dynamic criteria for investment decision making. It presents a practical numerical example for the value calculation of investment criteria Net Present Value and Internal Rate of Return for the reviewed investment project solutions. In this manner it is possible to make an orderly set of alternatives with clear preferences for the most suitable alternative in comparison with other ones. Such rating of project solutions will enable the decision maker to emphasize advantages with more arguments and select the most suitable project solution in accordance with the established criteria, conditions and limitations.
\end{abstract}

Key words: Development Investment Projects, Production program, Dynamic criteria

\section{INTRODUCTION}

Directing the program orientation of a company is of crucial importance for the survival and development of a company. By defining their own development, in accordance with market needs, a company strengthening the competitiveness and perform its mission in an area which presents its business. Growth and development of companies has the most effective realization by approach of appropriate optimization of the production program. On the basis of the production the program is performing a choice of technology and capacity, estimates incomes and costs, efficiency, effectiveness and performance of the investment at all.

Possibility of strategic selection of products in the process of optimization of the enterprise programme orientation must be carefully reviewed through a number of assessing criteria in order to make rational decisions. In such context it is necessary to identify relevant criteria indicators that in appropriate manner represent a complex nature of the optimization process of the programme orientation, providing thereby to take into account external and internal impacts on each product from the production programme. In that sense, in the paper (Vesic Vasovic et al., 2011) are emphasized some methodological aspects of decision making on the production programme in an industrial enterprise and some options for the decision maker to control the process of multicriteria optimization and participate in the selection of the final solution.

The choice of optimal development programs results in a substantial and long-term consequences in all aspects of the business. The high degree of integration in modern production and the world 
economy, dependence on imported materials and technological machines and competition in the global market impose a need for a marked selectivity within the existing programs and especially within the new development programs in the industry.

The complexity of evaluation process and selection of development investment project imposes the need for a complex approach, i.e. application of estimated dynamic criteria. In spite of the numerous criteria available, virtually the only ones used to determine whether to reject or to accept a project have been the net present value (NPV) and internal rate of return (IRR). These criteria represent the dynamic aspect of investing and they are suitable for economic evaluation of the project from the aspect of society, organization and the bank.

\section{THE SPECIFICS OF APPLICATION OF DISCOUNTED INVESTMENT APPRAISAL TECHNIQUE}

Many of the surveys have reported an increasing use of the discounted cash flow investment appraisal methods. The research (Akalu, 2003) is focused on how these companies perform investment appraisal, subsequent follow-up and measurement of project success or failure. Analysis of investment criteria related to both the investors' and lenders' perspectives is shown in the paper (Borgonovo et al., 2010). Radojicic et al. (2011) focuses on analyzing and defining criteria for the formation of multiple-criteria model for ranking investment proposals. Given the uncertainties and resource limitations over the planning period, the objective is to maximize the expected total discounted return or the expectation of some other function for all projects over a long time horizon (Solak et al., 2010). The aim of the paper (Cortelezzi and Villani, 2012) is to analyze the equilibrium strategies of two firms competing for a two-stage sequential R\&D investment, when a firm may infer a private signal from the strategy played by the other.

The results of testing three investment decision criteria with more traditional criteria through simulation are discussed (Thompson and Thuesen, 1987). The internal rate of return is often used by managers and practitioners for investment decisions. The research findings (Brijlal and Quesada, 2009) suggest that the Payback Period (PP) technique (39\% of respondents) was the popular technique used by managers in evaluating capital budgeting decisions. This was followed (Table 1) closely by the Net Present Value (NPV) technique (36\%), Internal Rate of Return - IRR (28\%), Profitability Index - PI (28\%) and Accounting Rate of Return - ARR (22\%). The aim of the paper (Biezma and San Cristóbal, 2006) is to develop a clear description and understanding of the uses and limitations of many different project evaluation techniques and to show when these methods are connected and are applicable to cogeneration plants. In spite of the numerous criteria available, virtually the only ones used to determine whether to reject or to accept a project have been the net present value (NPV), internal rate of return (IRR) and payback period (PP).

Investment appraisal is used to look at a potential capital investment by a firm and measure it's potential value to the firm. There is more than one method of investment appraisal, and each different method allows the potential return on the investment to be examined in a different way. Investment appraisal techniques can help them to choose the best option (Kaplan Financial, 2012). Investment profitability analysis (UNIDO, 1986) is the measurement of the profitability of the resources put into a project, more directly the return on the capital no matter what the sources of financing.

As a result, most medium-sized and large organizations have developed special procedures and methods for dealing with these decisions. A systematic approach to capital budgeting implies (Carter et al., 1997):

a) the formulation of long-term goals

b) the creative search for and identification of new investment opportunities

c) classification of projects and recognition of economically and/or statistically dependent proposals

d) the estimation and forecasting of current and future cash flows

e) a suitable administrative framework capable of transferring the required information to the decision level

f) the controlling of expenditures and careful monitoring of crucial aspects of project execution

g) a set of decision rules which can differentiate acceptable from unacceptable alternatives is required.

The agenda proposed for project appraisal is structured in six steps (European Commission, 2008). Some of these steps are preliminary but 
necessary requirements for cost-benefit analysis: context analysis and project objectives, project identification, feasibility and option analysis, financial analysis, economic analysis, risk assessment. The process Feasibility and option analysis aims at providing evidence that the project choice can actually be implemented and is the best option among all feasible alternatives.

The effects of investing represent the measure of accomplishment of given investment goals, which is why they are used as criteria for evaluating the efficiency of investment projects. Companies are primarily interested in economic effects expressed by material benefit (direct effects of importance to companies such as profit, accumulation etc.), although a social community has indirect benefit. Uneconomic effects have ecological, community, social, defence and other importance that can sometimes, if we take into account the overall investment efficiency, can overcome the importance of economic effects, both in positive and negative sense.

The optimization of investment options is an important consideration for an company if it is to remain competitive in an ever demanding market. The calculation of investments is an expensive tool of enterprise management used in planning the investments. It can be perceived as the harmonization and evaluation of the models for investment decision-making.

\section{NUMERICAL EXAMPLE OF CALCULATING NPV AND IRR CRITERIA}

The demonstration of determining the most profitable investment project will be performed on the numerical example, where it was necessary to determine the most favourable one out of five offered projects. The practical numerical example of calculating the values of investment criteria NPV and IRR was made for 6 considered development and investment projects $\left(\mathrm{DIP}_{1}, \mathrm{DIP}_{2}\right.$, $\mathrm{DIP}_{3}, \mathrm{DIP}_{4}, \mathrm{DIP}_{5}$ and $\mathrm{DIP}_{6}$ ). The value of investment project $\left(I_{j}\right)$ for each of the compared projects as well as of the expected accumulation value made by project exploitation during each of the five years of anticipated project exploitation period $\left(\mathrm{t}_{\mathrm{i}}\right)$ are presented in Table 1 .

Table 1 Values if investment and expected accumulation

\begin{tabular}{|c|c|c|}
\hline Project (label) & Investment project value (\$) & Expected accumulation value (\$/years) \\
\hline DIP $_{\mathbf{1}}$ & $46 \cdot 10^{6}$ & $14 \cdot 10^{6}$ \\
\hline DIP $_{\mathbf{2}}$ & $33 \cdot 10^{6}$ & $11 \cdot 10^{6}$ \\
\hline DIP $_{\mathbf{3}}$ & $22 \cdot 10^{6}$ & $8.65 \cdot 10^{6}$ \\
\hline DIP $_{\mathbf{4}}$ & $29 \cdot 10^{6}$ & $10.3 \cdot 10^{6}$ \\
\hline DIP $_{\mathbf{5}}$ & $44 \cdot 10^{6}$ & $14.8 \cdot 10^{6}$ \\
\hline DIP $_{\mathbf{6}}$ & $58 \cdot 10^{6}$ & $16.5 \cdot 10^{6}$ \\
\hline
\end{tabular}

With the aim to select the best investment project according to NPV and IRR criteria, appropriate calculations (Radojicic, 2009) were made and NPV values were gained for each of the projects for various values of discount factor $(p)$ which is presented in Table 2.

Estimation of validity of investment projects realisation implies the comparison of performed investments and effects achieved by projects exploitation. In order to provide conditions for comparing these values, it is necessary to reduce them to appropriate values at the same moment of time, i.e. to perform their discounting. Discounting starts with the future value and converts the future value to a present value, which is the cash equivalent now of the future value. In the calculations above we were converting each cash flow into its present value by effectively multiplying by a discount factor.

\section{Net Present Value (NPV):}

For the project DIP:

$$
\begin{aligned}
& N N V_{D I P 1}=\sum_{n=1}^{5} F_{n} \cdot \frac{1}{(1+p)^{n}}-I_{P}= \\
& =\left.14 \cdot 10^{6} \cdot K_{P A}\right|_{p} ^{n}-46 \cdot 10^{6}
\end{aligned}
$$

Investment present value $\left(\mathrm{I}_{\mathrm{P}}\right)$ for project $\mathrm{DIP}_{1}$ : $\mathrm{I}_{\mathrm{Pl}}=\mathrm{I}_{\mathrm{DIP} 1}=46 \cdot 10^{6}(\$)$.

Factor: $K_{P A}=\frac{(1+p)^{n}-1}{p(1+p)^{n}}$, e.g. for: $\mathrm{p}=10 \%$ and $\mathrm{n}=5$ years

$$
\left.K_{P A}\right|_{10} ^{5}=\frac{(1+0.1)^{5}-1}{0.1 \cdot(1+0.1)^{5}}=3.7908
$$


present project value $\mathrm{DIP}_{1}$ for discount rate $\mathrm{p}=$ $5 \%$ is:

$$
\begin{aligned}
& N N V_{D I P 1}(p=5 \%)= \\
& =14 \cdot 10^{6} \cdot 4.3295-46 \cdot 10^{6}= \\
& =14.613 \cdot 10^{6}(\$)
\end{aligned}
$$

Factor $\mathrm{K}_{\mathrm{PA}}$ needs not to be calculated but it can be easier adopted from tables for suitable conditions:
$\mathrm{K}_{\mathrm{PA}}=f(p, n)$ e.g. for $\mathrm{n}=5$ years and particular value of discount factor (Table 2).

Using the presented procedure, values of NPV criteria were calculated for different values of discount rate for alternative investment projects included in Table 3.

Graphic presentation of NPV change depending on the change in discount rate is depicted in Figure 1.

Table 2: Value of $K_{P A}$ factor depending on discount rate

\begin{tabular}{|c|c|c|c|c|c|c|c|}
\hline \multirow{2}{*}{ Project } & \multicolumn{7}{|c|}{ Discount Rate } \\
\hline & $5 \%$ & $10 \%$ & $15 \%$ & $20 \%$ & $25 \%$ & $30 \%$ & $35 \%$ \\
\hline $\mathrm{DIP}_{1}$ & $14,613,000$ & $7,071,200$ & 930,800 & $-4,131,600$ & $-8,349,800$ & $-11,910,000$ & $-14,921,400$ \\
\hline $\mathrm{DIP}_{2}$ & $14,624,500$ & $8,698,800$ & $3,874,200$ & $-103,400$ & $-3,417,700$ & $-6,215,000$ & $-8,581,100$ \\
\hline $\mathbf{D I P}_{3}$ & $15,450,175$ & $10,790,420$ & $6,996,530$ & $3,868,690$ & $1,262,445$ & $-937,250$ & $-2,797,865$ \\
\hline DIP $_{4}$ & $15,593,850$ & $10,045,240$ & $5,527,660$ & $1,803,180$ & $-1,300,210$ & $-3,919,500$ & $-6,135,030$ \\
\hline $\mathbf{D I P}_{5}$ & $14,076,600$ & $6,103,840$ & $-387,440$ & $-5,739,120$ & $-10,198,360$ & $-13,962,000$ & $-17,145,480$ \\
\hline DIP $_{5}$ & $13,436,750$ & $4,548,200$ & $-2,688,700$ & $-8,655,100$ & $-13,626,550$ & $-17,822,500$ & $-21,371,650$ \\
\hline
\end{tabular}

\begin{tabular}{|c|c|c|c|c|c|c|c|}
\hline \multirow{2}{*}{$\begin{array}{c}\text { Factor } \\
\mathbf{K}_{\mathbf{P A}}\end{array}$} & $5 \%$ & $10 \%$ & $15 \%$ & $20 \%$ & $25 \%$ & $30 \%$ & $35 \%$ \\
\cline { 2 - 8 } & 4.3295 & 3.7908 & 3.3522 & 2.9906 & 2.6893 & 2.435 & 2.2199 \\
\hline
\end{tabular}

Table 3: Net Present Value

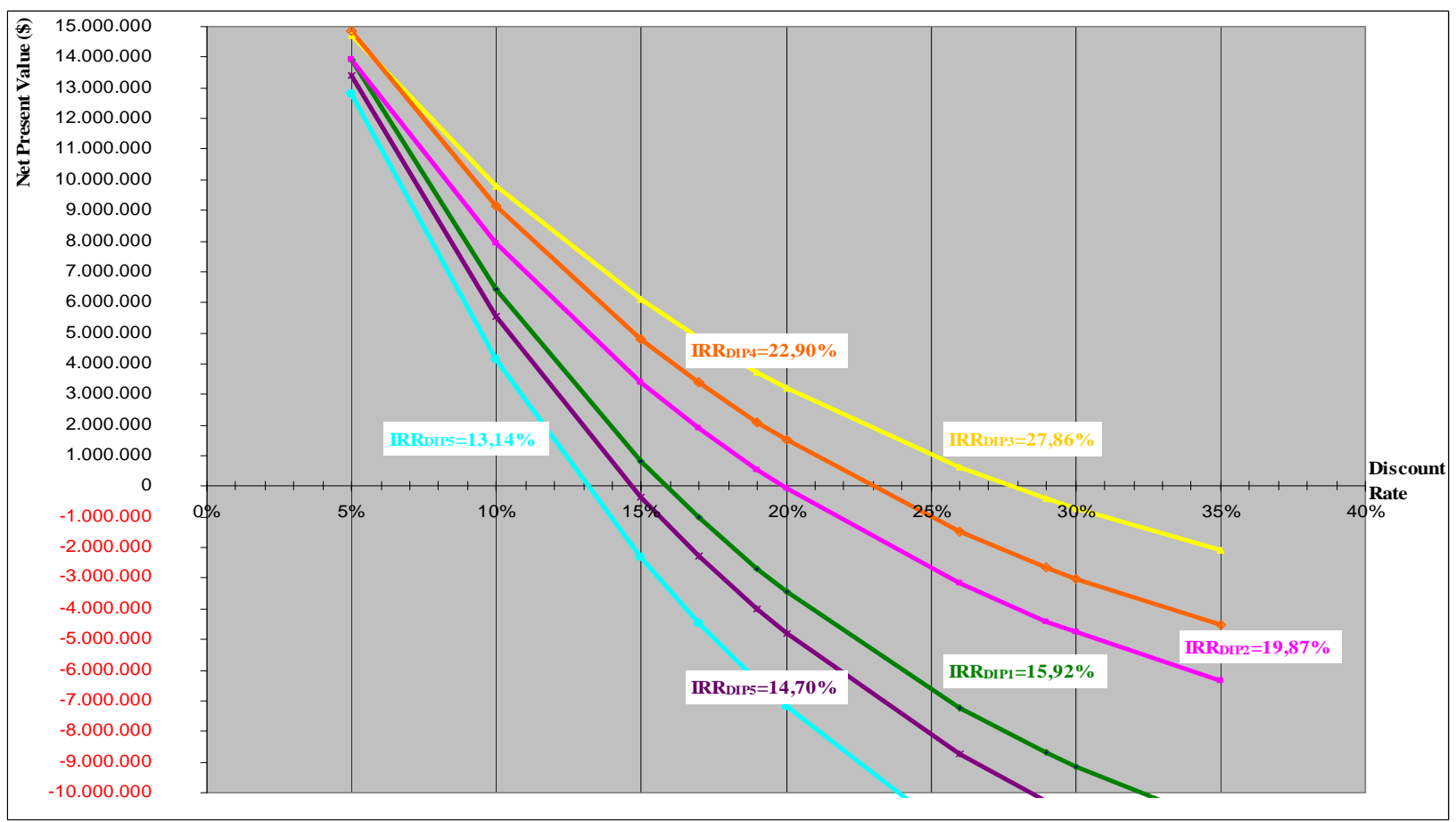

Figure 1: Comparative presentation of change in investment projects NPV

The rate of discount (UNIDO, 1986) should be based as far as possible on the actual rate of interest in the capital market to reflect the time preference and opportunity cost of the possible alternative use of the capital invested. In case the investment is financed by long-term loans, the actual rate of interest paid should be taken as the discount rate. If no loans are used for financing a project, the rate of interest charged by the central bank on long-term loans should be adopted as the rate of discount. 
Values of IRR criteria for DIP $_{1}$ investment project are calculated by using the formula:

$$
\begin{aligned}
& I R R_{D I P 1}= \\
& =p_{1}+\frac{N P V_{1}}{N P V_{1}-N P V_{2}}\left(p_{2}-p_{1}\right)= \\
& =15+\frac{0.931 \cdot 10^{6}}{0.931 \cdot 10^{6}-\left(-4.132 \cdot 10^{6}\right)}(20-15) \approx \\
& \approx 15.92 \%
\end{aligned}
$$

Where:

- $\mathrm{p}_{1}$ is actualization rate for which the net present value $\mathrm{NPV}_{1}$ exceeds $0\left(\mathrm{NPV}_{1}>0\right)$

- $\mathrm{p}_{2}$ is actualization rate for which the net present value $\mathrm{NPV}_{2}$ is below $0\left(\mathrm{NPV}_{1}<0\right)$

Values of IRR criteria were calculated for other alternative projects and included in Table 4 . Position rankings of the compared investment projects according to IRR criterion are presented in Table 4.

Table 4: Project rankings according to IRR
criterion
\begin{tabular}{|c|c|c|}
\hline Rank & Project (Label) & IRR \\
\hline 1 & IIP $_{3}$ & $27.86 \%$ \\
\hline 2 & DIP $_{4}$ & $22.90 \%$ \\
\hline 3 & DIP $_{2}$ & $19.87 \%$ \\
\hline 4 & DIP $_{1}$ & $15.92 \%$ \\
\hline 5 & DIP $_{5}$ & $14.70 \%$ \\
\hline 6 & DIP $_{6}$ & $13.14 \%$ \\
\hline
\end{tabular}

It may be concluded that on the basis of such calculation a set of alternatives was gained with clear preferences of $\mathrm{DIP}_{3}$ alternative with regard to other compared ones.

\section{CONCLUSION}

Decision-making related to investments and selection of the most favourable alternative represents one of the most important managerial activities which take place in various business areas. The accomplishment of investment project goals implies analysis and comprehensive estimation of relevant elements of the investment project on one hand, with necessary conclusions based on optimization process results; on the other hand, it implies investment project realisation in line with foreseen investment programme performances.

Companies use various project evaluation techniques to determine the feasibility and profitability of a project. Within the evaluation of investment projects, it is necessary to take into account all the advantages and expected effects of evaluated project application. Measuring of total effects brought by exploitation of one investment project and their quantitative expression by particular criteria makes it possible to estimate whether the expected effects will exceed the total necessary investments. By applying criteria such as Net Present Value and Internal Rate of Return, conditions are made for evaluation of economic effects, as well as for comparing and rating alternative project solutions.

Based on project evaluation, the investment decision on acceptance or non-acceptance of particular project realisation is made, but never disregarding the fact that at the end of all calculations and measuring it is a human being who makes the investment decision, taking into account immeasurable effects which were not included into calculations, but influence the selection significantly.

\section{REFERENCES}

Akalu, M. M. (2003). The process of investment appraisal: the experience of 10 large British and Dutch companies. International Journal of Project Management, 21(5), 355-362.

Basic investment appraisal techniques. (2012). Retrieved 15.03.2014, from Kaplan Financial http://kfknowledgebank.kaplan.co.uk/KFKB/Wiki\% 20Pages/Basic\%20investment\%20appraisal\%20tech niques.aspx? mode $=$ none

Biezma, M. V., \& San Cristóbal, J. R. (2006). Investment criteria for the selection of cogeneration plants-a state of the art review. Applied Thermal Engineering, 26(5), 583-588.

Borgonovo, E., Gatti, S., \& Peccati L. (2010). What drives value creation in investment projects? An application of sensitivity analysis to project finance transactions. European Journal of Operational Research, 205(1), 227-236.

Brijlal, P., \& Quesada, L. (2009). The Use Of Capital Budgeting Techniques In Businesses: A Perspective From The Western Cape. The Journal of Applied Business Research, 25(4) 37-46.

Carter, S., Macdonald, N. J., \& Cheng, D. C. B. (1997). Basic finance for marketers. Food and Agriculture Organization of the United Nations.

Cortelezzi, F., \& Villani, G. (2012). Strategic R\&D Investment Under Information Revelation. The Engineering Economist, 57(1) 20-40.

Guide to Cost Benefit Analysis of Investment Projects: Structural Funds, Cohesion Fund and Instrument for Pre-Accession (2008). Retrieved 15.03.2014, from European Commission - Directorate General Regional Policy http://ec.europa.eu/regional_policy/sources/docgener /guides/cost/guide2008_en.pdf 
Radojicic, M. (2009). Practicum in management of development investment projects. Tehnical Faculty Cacak. (In Serbian)

Radojicic, M., Nesic, Z., Vesic Vasovic, J., SpasojevicBrkic, V., \& Klarin M. (2011). One approach to the design of an optimization model for selection of the development strategy. Technics Technologies Education Management, 6(1) 99-110.

Solak, S., Clarke, J.-P. B., Johnson, E. L., \& Barnes, E. R. (2010). Optimization of R\&D project portfolios under endogenous uncertainty. European Journal of Operational Research, 207(1) 420-433.

Thompson, R. A., \& Thuesen, G. J. (1987).

Applications of Dynamic Investment Criteria for
Capital Budgeting Decisions. The Engineering Economist, 33(1) 59-86.

UNIDO. (1986). Manual for evaluation of industrial projects. Retrieved 15.05.2013, from United Nations Industrial Development Organization http://www.unido.org/fileadmin/user_media/Publicat ions/download/Manual_for_Evaluation_of_Industria 1_Projects.pdf

Vesic Vasovic, J., Radojicic, M., Klarin, M., Spasojevic-Brkic, V. K. (2011). Multi-criteria approach to optimization of enterprise production programme. Proceedings of the Institution of Mechanical Engineers, Part B - Journal of Engineering Manufacture, 225(10) 1951-1963. 